\title{
Species composition and richness of viable seed bank after fire events in Mount Ciremai National Park and Kuningan Botanic Gardens, West Java, Indonesia
}

\author{
INDRIANI EKASARI ${ }^{1,2}$, RONGGO SADONO ${ }^{3, \bullet}$, DJOKO MARSONO ${ }^{4}$, JOKO R. WITONO \\ ${ }^{1}$ Doctoral Program, Faculty of Forestry, Universitas Gadjah Mada, Jl Agro No 1, Bulaksumur, Sleman, Yogyakarta, Indonesia \\ ${ }^{2}$ Cibodas Botanic Gardens, Indonesian Institute of Sciences. J1 Kebun Raya Cibodas, Cipanas, Cianjur 43253, West Java, Indonesia. \\ ${ }^{3}$ Department of Forest Management, Faculty of Forestry, Universitas Gadjah Mada, Jl Agro No 1, Bulaksumur, Sleman 55281, Yogyakarta, Indonesia \\ Tel./fax.: +62-274-548815, `email: rsadono@ugm.ac.id. \\ ${ }^{4}$ Department of Forest Resources Conservation, Faculty of Forestry, Universitas Gadjah Mada, Jl Agro No 1, Bulaksumur, Sleman 55281, Yogyakarta, \\ Indonesia \\ ${ }^{5}$ Research Center for Plant Conservation and Botanic Gardens-Indonesian Institute of Sciences. J1 Ir. H. Juanda No. 13, Bogor 16122, West Java, Indonesia
}

Manuscript received: 23 April 2021. Revision accepted: 28 May 2021

\begin{abstract}
Ekasari I, Sadono R, Marsono D, Witono JR. 2021. Species composition and richness of viable seed bank after fire events in Mount Ciremai National Park and Kuningan Botanic Gardens, West Java, Indonesia. Biodiversitas 22: 3437-3447. Forest fire is an environmental disaster that can decline ecosystem function and restoration efforts must be considered to restore forest ecosystems after fire events. Natural regeneration using existing soil seed banks is a promising approach in restoration due to its advantage in terms of minimizing cost. This study aimed to examine the species composition and richness of germinable seed banks in several post-fire sites in Mount Ciremai National Park (MNCP) and Kuningan Botanic Gardens (KGB), West Java, Indonesia. One hundred fifty-eight soil samples were collected from the study sites representing fire events (i.e., four post-fire sites and one non-fire site), and soil depths (i.e., upper, middle, and lower). The collection of soil samples and identification of seedlings emergence were conducted from September 2019 to February 2020. Data were analyzed using ANOVA and correspondence analysis using SPSS Version 22. In total, 4626 emergence seedlings were recorded, belonging to 158 species and 58 families in which 41 families in the upper soil layer, 35 families in the middle soil layer, and 33 families in the lower soil layer. The results showed that Poaceae, Asteraceae, and Euphorbiaceae as the most dominant families. The upper soil layer of post-fire site 2018 had the highest species richness $(\mathrm{R}=11.98)$, while the lower soil layer of post-fire site 2012 had the lowest species richness $(R=2.64)$. Our findings suggest that when carrying out restoration activities in postfire areas, it is preferable to use native species that do not compete with species persisted in soil seed banks.
\end{abstract}

Keywords: Post-fire forest, seedlings emergence, soil seed bank, soil layers

\section{INTRODUCTION}

Forest fire is an environmental disturbance triggered by several factors including change in climate condition caused by a long dry period, fuel accumulation caused by vegetation degradation, village livelihoods, and ignition sources caused by anthropogenic and natural factors. Forest fire can alter vegetation structure and composition on spatial and temporal basis. In addition, forest fire might also change the balance of energy, ecosystem homeostasis and ecological integrity of forest ecosystem. The spatial patterns of forest fires at a landscape scale are determined by a combination of various biophysical conditions, such as topography, forest edge, and anthropogenic factors (Tian et al. 2013; Chen et al. 2014; Numata et al. 2017; Santika et al. 2020).

Forest and landscape restoration is required to recover ecosystem degradation after forest fire. In doing so, several aspects need to be considered in the restoration including spatial patterns of landscape configuration, level of sociopolitical variables for management authorities planning and decision making (Budiharta et al. 2014; Araújo et al. 2017), vegetation degradation, restoration cost, and the best restoration techniques. Among such aspects, the remnant species distribution, quantity and quality of the residual vegetation is a good indicator to assess the potential areas for natural regeneration to minimize restoration cost (Rodrigues et al. 2011; Chen et al. 2014). When doing restoration using natural regeneration techniques, the presence of seeds under the soils (often so-called soil seed banks) is a valuable resource to accelerate vegetation succession and to minimize restoration costs (Shang et al. 2016).

Soil seed bank is viable seeds found in the soil that has the potential to germinate and grow (He et al. 2016; Akinyemi et al. 2019). It is a key component of vegetation that influences ecosystem resilience The use of soil seed banks for vegetation regeneration has several advantages over other vegetation recovery methods in terms of maintaining local ecosystem balance, including protecting local native species (He et al. 2016). However, there is limited knowledge regarding the ecology of soil seed banks especially those which occur in degraded lands (Zhang and Chu 2013), including in disturbed forest after fire.

During vegetation succession following disturbance, Randriamalala et al. (2015) stated that there are three succession stages, namely (i) the early stage (1-5 years) which is dominated by herbaceous species, (ii) the middle 
stage (6-10 years) which is characterized by wind-dispersed shrubby species, and (iii) the late stage (11-29 years) which is characterized by the dominance of animal-dispersed shrubby or woody species. In regard to seed ecology, herbaceous and shrub plants generally dominate soil seed bank in the early years of vegetation succession, and these groups of plant are able to persist under harsh condition and can actively return to the ecosystem without the need for re-introduction (Daïnou et al. 2011; Girard et al. 2017).

The aim of this study was to examine the species richness and composition of germinable seed banks in several post-fire sites in Mount Ciremai National Park (MNCP) and Kuningan Botanic Gardens (KGB), West Java, Indonesia. These two areas provide excellent context of landscape disturbed by forest fires in the tropical region (Ekasari et al. 2020). Mount Ciremai National Park represents an in-situ conservation area while Kuningan Botanic Gardens represents an ex-situ conservation site, and both conservation areas are located side by side but with separate management authorities. The MCNP is managed by the Ministry of Environment and Forestry (central government) and $\mathrm{KBG}$ was managed by the Kuningan Environmental Agency (local government). In addition to fire, more than half of the MCNP area is in heavily degraded condition as a result of agriculture and illegal logging (Gunawan 2015).

\section{MATERIALS AND METHODS}

\section{Study area and period}

This study was conducted in Mount Ciremai National Park (MNCP) and Kuningan Botanic Gardens (KGB), West Java Province, Indonesia (Figure 1). The area of MCNP is 15,859 ha and located between $108^{\circ} 28^{\prime} 0^{\prime \prime}$ $108^{\circ} 21^{\prime} 35^{\prime \prime} \mathrm{E}$ and $6^{\circ} 50^{\prime} 25^{\prime \prime}-6^{\circ} 58^{\prime} 26^{\prime \prime} \mathrm{N}$ at an altitudinal range of 800 to 3,078 meter above sea level (m asl). The annual rainfall is between 2000 to $4000 \mathrm{~mm}$ per year and the annual temperature is between $15^{\circ}$ to $27^{\circ} \mathrm{C}$, and on the top of Mount Ciremai the annual temperature is between $4^{\circ}-18^{\circ} \mathrm{C}$ (Ismail et al. 2019). KBG has an area of 172 ha and is located at $108^{\circ} 24^{\prime} 10.37^{\prime \prime} \mathrm{E}$ and 6 $6^{\circ} 9^{\prime} 1.9^{\prime \prime} \mathrm{N}$ (Bogor Botanic Gardens 2016) at an altitudinal range of 490 to 870 $\mathrm{m}$ asl. This botanic garden serves as a site window of MCNP flora. Fieldwork for data and soil samples collection at all sites were done in late dry season September-October 2019. Seed germination, seedlings identification, and data analysis were conducted from November 2019 to June 2020.
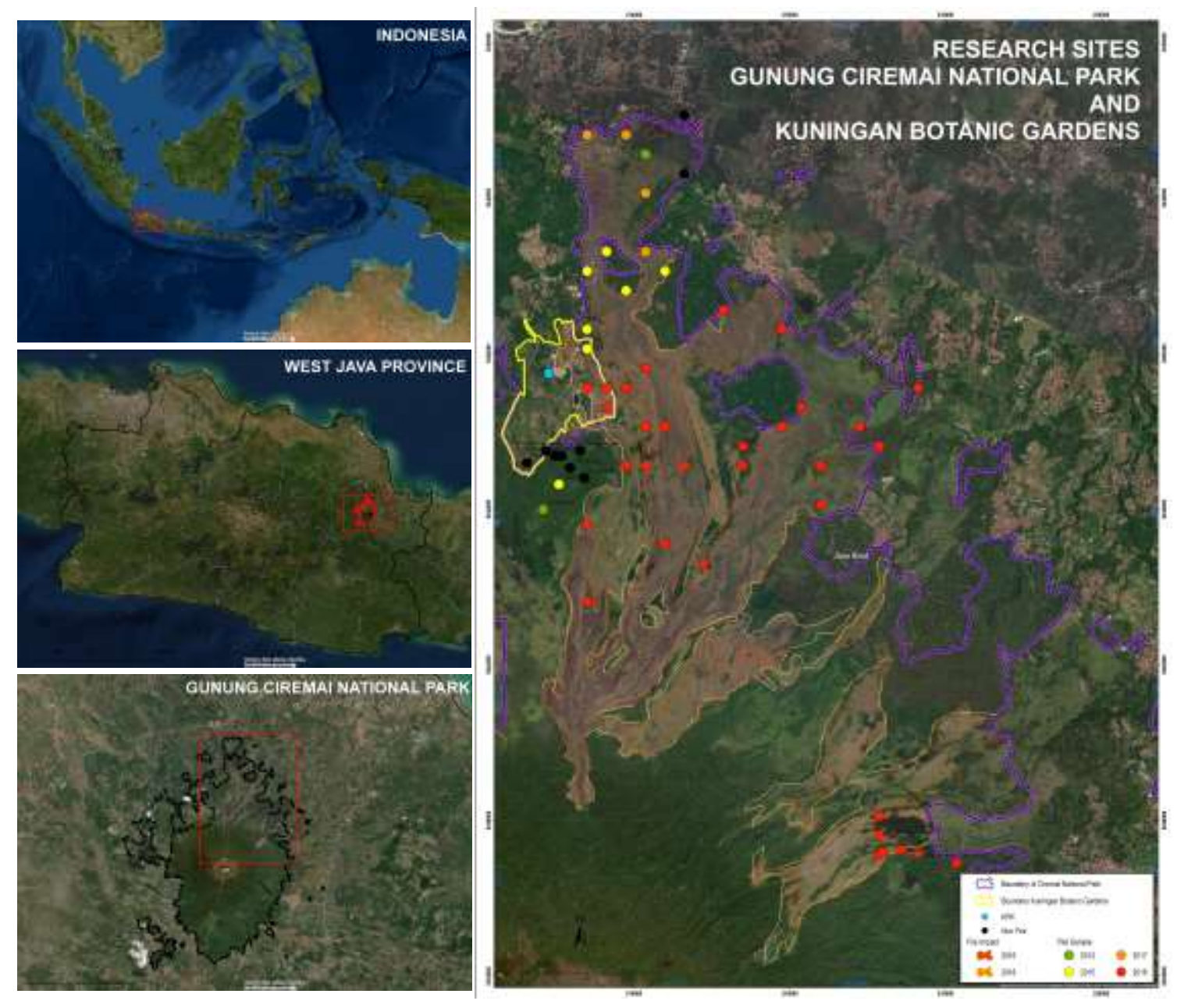

Figure 1. The study sites in Mount Ciremai National Park and Kuningan Botanic Gardens (i.e., non-fire, post-fire 2012, post-fire 2015, post-fire 2017, and post-fire 2018) (Google Earth 2019). 
This research used field survey method to collect data in five sites representing fire events between 2012 to 2018 (i.e., non-fire, post-fire 2012, post-fire 2015, post-fire 2017 and post-fire 2018) (Figure 1). According to MCNP authority, the post-fire 2018 had the greatest ecological and economic effects, including local extinction of species and a decrease in ecotourism revenue as compared to previous years. As a result, the effect of the fire in previous years was obscured. In general, there are differences in species dominance across the observed sites due to various forms and levels of disturbance severity besides the influence of topography and altitudes.

\section{Procedures}

The Google Earth (2019) map was the base map used to determine the collection plot of soil samples as a grid with a distance between points $200 \times 200 \mathrm{~m}$. To prevent the side effect of seed rain from the nearby forest, the observed plots were distributed using stratified random sampling method by locating plots on five sites based on perpendicular distance from the forest edge of $25 \mathrm{~m}$ (Benoit et al. 1989; Daïnou et al. 2011; Galloway et al. 2017; Sulistyawati and Fitriana 2017). The placement of soil sampling also took into account the elevation gradients to represent all elevations (Luo et al. 2017). Elevation gradients in this study ranged from an altitude 220 to 1125 $\mathrm{m}$ asl. The observation in the field covered an area of 828 ha to include post-fire area and non-fire area, namely postfire site 2012 (3 plots), post-fire site 2015 (7 plots), postfire site 2017 (4 plots), post-fire site 2018 (32 plots) and non-fire site ( 8 plots) (Table 1$)$. Each site had a different number of plots which was determined by the visibility according to the map in 2019. The majority of the post-fire sites were destroyed by fires in 2018 , and some have been converted into thematic botanical collections within the KBG. The number of plots in the MCNP and KBG areas was also different in which forest fires in MCNP had a larger scale.
At least 60 sampling units should be collected to investigate soil seed banks (Benoit et al. 1989). To determine the vertical distribution of seeds at each fire condition, the number of seedlings (density) within similar soil layer/depth were counted. Using sharp knife, the depth of the soil was stratified into three layers, namely $0-5 \mathrm{~cm}$ (upper), 6-10 cm (middle) dan 11-15 cm (lower) (Shang et al. 2016; Zida et al. 2020). To investigate the composition, density and vertical distribution of viable soil seed banks, soil samples were taken using hammering hollow with square metal frame with size of $20 \times 20 \times 5 \mathrm{~cm}$ (Zida et al. 2020). In total 158 soil samples from five site plots were collected. The data collecting sites were varied in terms of soil depth, post-fire 2018 sites were mostly rocky and cliff, therefore some plots could only be taken in two layers (upper and middle).

The procedure of soil sample treatment and seedling identification followed previous studies (Siahaan et al. 2014; Santos et al. 2016; Zida et al. 2020). Soil samples were stored in plastic bags with label (soil samples had weight between 0.8 to $2.9 \mathrm{~kg}$ per bag) and transported to the Silviculture Laboratory, Faculty of Forestry, Gadjah Mada University (UGM) in Yogyakarta for germination purpose. The soil samples were spread in 40x30x10 cm trays and arranged in greenhouse with an ideal and uniform condition (the average temperature was $30.7^{\circ} \mathrm{C}$ and the average humidity was $66.4 \%$ ). Five trays from each site containing sterilized soil samples were used as control treatments. The trays were kept continuously moist by daily watering and monitored over a 4-month period (November 2019 to February 2020). The emerging seedlings of each soil sample were identified, counted number and recorded the date of germination, plot number, soil layer, and site in which the sample was collected. All sample species were dried and collected as herbarium vouchers in the Faculty of Forestry, UGM. Identification of the species and families of seed emergence used Weeds of Rice in Indonesia (Soerjani et al. 1987) and A Guide Book to Invasive Alien Plant Species in Indonesia (Setyawati et al. 2015).

Table 1. Soil samples collected from four post-fire and non-fire sites in Mount Ciremai National Park and Kuningan Botanic Gardens, West Java, Indonesia

\begin{tabular}{|c|c|c|c|c|c|}
\hline Conservation area & Site & Elevation (m asl) & No. of plots & No. of soil layers* & $\begin{array}{c}\text { No. of soil } \\
\text { sample }\end{array}$ \\
\hline \multirow{9}{*}{ Mount Ciremai National Park } & Non-Fire & $244-842$ & 7 & 3 & 21 \\
\hline & Post-fire 2012 & $252-960$ & 2 & 3 & 6 \\
\hline & & 220 & 1 & 2 & 2 \\
\hline & Post-fire 2015 & $316-902$ & 6 & 3 & 18 \\
\hline & & 462 & 1 & 2 & 2 \\
\hline & Post-fire 2017 & 273 & 3 & 3 & 9 \\
\hline & & $275-427$ & 1 & 2 & 2 \\
\hline & Post-fire 2018 & $436-1125$ & 25 & 3 & 75 \\
\hline & & $438-740$ & 4 & 2 & 8 \\
\hline \multirow{3}{*}{ Kuningan Botanic Gardens } & Non-Fire & 870 & 1 & 3 & 3 \\
\hline & Post-fire 2015 & 601 & 1 & 3 & 3 \\
\hline & Post-fire 2018 & $600-630$ & 3 & 3 & 9 \\
\hline Total soil sample & & & & & 158 \\
\hline
\end{tabular}

Note: 3 soil layers (upper, middle, lower), 2 soil layers (upper, middle) 


\section{Data analysis}

The species composition and richness were important parameters to evaluate ecosystem conditions (Davari et al. 2011). The seedling emergence method was applied for its ability to quantitatively and qualitatively determine the viable fraction of readily germination seeds which is the most important component of soil seed bank resources for restoration management (Zida et al. 2020). To detect the effects of post-fire and depth of soil samples on the soil seed bank in terms of diversity and richness, the data were analyzed according to the procedures. Several indices were calculated, i.e. Important Value Index (IVI), ShannonWiener diversity index $\left(\mathrm{H}^{\prime}\right)$, and Margalef richness index (d) (Magurran 2004). IVI is used to determine the overall importance of a species in the community using its relative coverage that positively correlates with the abundance of each species and their relative frequency as below (Krebs 2014). For each species found in the seed bank, the absolute and relative density and frequency were estimated. It also was estimated for each morphospecies found in all sites.

Importance Value Index $=$ Relative Abundance $(\%)+$ Relative Frequency (\%)

Diversity index (H') reflects the stability of the species community and the complex function of the community. $\mathrm{H}^{\prime}$ was determined with the following formula:

$$
H^{r}=\sum_{i=1}^{s} \rho^{i} \ln \rho i
$$

Where:

$\mathrm{H}^{\prime}=$ Shannon-Wiener diversity index

$\rho \mathrm{i}=$ proportion of total sample belonging to species $i$

$\ln =$ natural $\log ^{1}$

Odum (1996) stated H' can be classified into three classes, namely high $\left(\mathrm{H}^{\prime}>3\right)$, medium $\left(1 \leq \mathrm{H}^{\prime} \leq 3\right)$ and low $\left(H^{\prime}>1\right)$.

Species richness has been commonly used to explore the relationship between biodiversity and ecosystem multifunctionality as the simplest measure of biodiversity. Increased species richness is beneficial to enhance ecosystem multifunctionality through positive interactions between species since every species with specific traits contributes differently to ecosystem function ( $\mathrm{Li}$ et al. 2021). Margalef species richness index was calculated using the formula:

$$
R=\frac{5-1}{\ln (N)}
$$

Where:

$R=$ Margalef richness index

$S=$ the total number of species

$N=$ the number of individuals

$\ln =$ natural $\log ^{1}$

Magurran (2004) said that species richness indexes were in high category $(\mathrm{R}>4)$, medium category $(2.5 \leq \mathrm{R} \leq 4)$ and low category $(\mathrm{R}>2.5)$.

The number of seedlings emergence and the number of species emergence was calculated as the average number of seedlings per square meter (at three layers of soil depth) from soil samples. A two-way ANOVA was used to analyze the differences in seed density across soil layers and period of fire events. The level of significance was set at $p<0.05$. Correspondence analysis was used to evaluate the relationship between emerged seedlings in terms of species composition and related environmental conditions (Zhang and Chu 2013). The plant cluster regulation could authentically reflect the growth habit of plants and the preference to soil nature, demonstrating that the soil properties will influence plants ( $\mathrm{He}$ et al. 2016). Correspondence analysis in SPSS version 22.0 was used to analyze all seeds emergence, and the factors that affect the occurrence of species from the non-fire site and post-fire sites on seed bank data. The results were interpreted as species assemblages in each soil layer representing non-fire sites and post-fire sites.

\section{RESULTS AND DISCUSSION}

\section{Species composition in soil seed banks}

In total, this study found 41 families in the upper soil layer, 35 families in the middle soil layer and 33 families in the lower soil layer. From the observed plots across five fire conditions, a total of 4626 emergence seedlings were found, belonging to 158 species and 58 families. The emergence seedlings that dominated were from post-fire site 2018 with 87 species in the upper soil layer, 78 species in the middle soil layer and 66 species in the lower soil layer (Table 2). Accordingly, the post-fire site 2018 had the highest total of emergence seedlings with 1309 seedlings in the upper soil layer, 864 seedlings in the middle soil layer and 582 seedlings in the lower soil layer. In contrast, the post-fire site 2012 had the lowest total number of emergence seedlings with 90 seedlings from 19 families in the upper soil layer, 79 seedlings from 17 families in the middle soil layer and 30 seedlings from 10 families in the lower soil layer.

Table 2. Total emergence seedlings and families at each fire condition in Mount Ciremai National Park and Kuningan Botanic Gardens

\begin{tabular}{lcccccccccc}
\hline \multirow{2}{*}{ Soil layer } & \multicolumn{2}{c}{ Non-fire site } & \multicolumn{2}{c}{ Post-fire site 2012 } & \multicolumn{2}{c}{ Post-fire site 2015 } & \multicolumn{2}{c}{ Post-fire site 2017 } & Post-fire site 2018 \\
\cline { 2 - 10 } & Seeds & Families & Seeds & Families & Seeds & Families & Seeds & Families & Seeds & Families \\
\hline Upper & 195 & 39 & 90 & 19 & 217 & 38 & 132 & 15 & 1309 & 87 \\
Middle & 380 & 41 & 79 & 17 & 206 & 42 & 47 & 19 & 864 & 78 \\
Lower & 335 & 40 & 30 & 10 & 114 & 29 & 46 & 12 & 582 & 66 \\
\hline
\end{tabular}


The highest number of emergence seedlings were found in the upper soil layer from four post-fire sites (post-fire 2012-post-fire 2018), while the non-fire site had the highest number of emergence seedlings in the middle soil layer. Dwipa et al. (2020) found that in a former wildfire forest in Mount Talang, West Sumatra, the soil seed bank was found in soil with depths ranging from 0 to $5 \mathrm{~cm}$. The total number of seeds in the soil tended to decrease as soil depth increased, and at the depth of $15-20 \mathrm{~cm}$, almost no soil seed bank was found.

Poaceae (17 species), Asteraceae (11 species), and Euphorbiaceae ( 7 species) were the most dominant families at the upper soil layer at the post-fire 2018 site (Figure 2). Similar pattern was also found in the post-fire site 2018 at the middle layer in which the dominant families were Poaceae (16 species), Asteraceae (8 species) then Euphorbiaceae, and Rubiaceae (7 species each). According to Gunawan (2015), Rubiaceae, Myrtaceae, and Fabaceae were found in abundance in the MCNP areas that suffering illegal logging and agriculture. According to Siahaan et al. (2014) and Zida et al. (2020) the families of Poaceae, Asteraceae, Fabaceae and Cyperaceae were the most common families found at the soil seed bank after prescribed fire, grazing, and species invasion in Indonesia and West Africa. Their dominance in the soil seed bank composition may be attributed to the fact that they had the most dispersal mechanisms. This implies their adaptability to disturbances, and there is a possibility that these families would need fire to break their seed dormancy (Zida et al. 2020). Seeds with lack of adaptation in dispersal ability may be eroded by disturbances, attacked by predators, or immediately germinate (Sileshi and Abraha 2014). The presence of a large number of species from the Poaceae family indicates that the post-fire ecosystems in the MCNP and KBG had adequate ecosystem resilience. A large number of seed banks of grass species in the soil also indicates that these species could eventually dominate the understory.

The result revealed that almost no species of trees were found in the soil seed bank on the post-fire 2018 site which is likely due to the frequent fire that occurred at the site (Figure 2). One of the most significant characteristics of this location that it was situated on a steep slope which might cause a frequent strong wind blow. The dominance of wind-dispersed seeds, which were generally herbaceous (i.e., Asteraceae and Poaceae), was reflected in the seed banks of the first stage of succession. The lightest seeds, Poaceae and Asteraceae, arrived first on the site, germinated, and filled the topsoil (Randriamalala et al. 2015). Furthermore, microclimatic variability was an important factor in post-fire germination and establishment, and in persistence of surviving flora (Tucker and Kashian 2018), while other environmental parameters such as light density, $\mathrm{pH}$, soil nutrient, water availability, and soil temperature influenced grass, shrubs, and herbs (He et al. 2016; Piiroinen et al. 2017; Huebner et al. 2018; Mwendwa et al. 2020). These two families were found abundantly on post-fire site 2018, while post-fire site 2012 had the smallest number of families. On the post-fire site in 2012, 14 families were discovered in the upper soil layer with three species belonging to the Asteraceae family. In postfire forest 2012, there were 13 and 9 families in the middle soil layer and lower soil layer, respectively. The only woody species found were Paraserianthes falcataria (L.) I.C.Nielsen, Trema orientale Blume, Leucaena leucocephala (Lam.) de Wit and Calliandra tetragona Benth. Tucker and Kashian (2018) stated that the branches of these tree or remnant trees were used as perches or fruit sources for bats or birds as seed dispersers, implying that they may play an important role in forest regeneration.
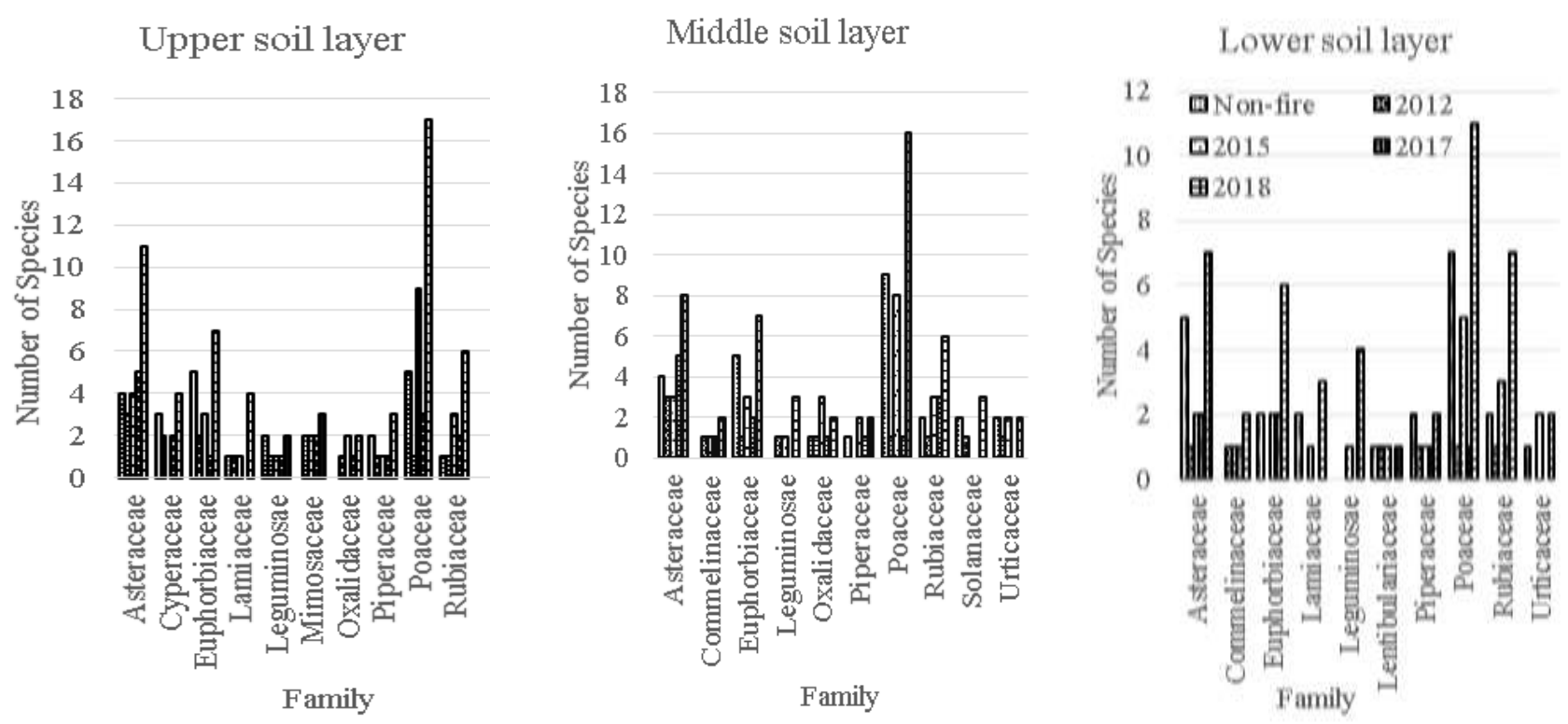

Figure 2. Ten families with the highest number of species in which their seeds were found across three soil layers and five fire conditions in MCNP and KBG 


\section{Effect of fire events and soil depths on emergence seedlings}

The post-fire 2018 had a significantly higher number of seedlings emergence and number of species emergence at $5 \%$ confidence level according to Analysis of Variance (Table 3). While soil depths did not have a significant difference in the number of seedlings, yet the lower soil layer had a significantly lower number of species emergence. In this case, the variations were most likely due to outside influences that fell into the upper soil layer, but the contribution did not reflect the size of the soil seed bank in the middle and lower soil layers (Siahaan et al. 2014; Douh et al. 2018). There were several factors that contributed to the variations in seedling emergence between the five fire condition sites, such as land rehabilitation or even ecotourism. Randriamalala et al. (2015) said that heavy tillage regime and light tillage regime are associated with decreases in the proportion of viable seeds.

At the lower soil layer, the overall number of species was lower than that in the upper soil layer. Some species have a long-term persistent seed as shown by their presence in the lower soil layer. Zhang and Chu (2013) found that a long-term persistent seed still existed even when erosion on the rehabilitated quarries was occurring. According to our result, fire selectively enhanced the germination and emergence of certain herbs and shrubs species that had not emerged in previous fire events and in the non-fire location. This finding is in contrast with Akinyemi et al. (2019) that said the fire effects on soil seed banks actually reduced the seed density in early year sites while some herbaceous species, such as Peperomia pellucida (L.) Kunth, Physalis angulata L., Phyllanthus amarus Schumach. \& Thonn. and Borreria verticillata (L.) G.Mey, emerged in the first few weeks after fire. Herbaceous species, in particular, play an important role in the ecosystem's functioning and have a major impact on the dynamics of the next woody plant succession. Herbs and shrubs also shield woody species seedlings from the effects of rain and aid in the retention of their seeds on the soil surface (Santos et al. 2016). On the other hand, given the annual variance in the floristic composition of seed banks, soil sampling time is also critical when determining seed bank richness.

Three dominant species of seedling emergence from each post-fire site and non-fire site are shown in Table 4. The result showed that the number of soil seed banks and important value index (IVI) decreased with soil depth. Siahaan et al. (2014), Randriamalala et al. (2015) and Zida et al. (2020) also found similar result with our study the composition and density of weed tend to be lower in deeper soil depth. Herbaceous species dominated this study, for example, Commelina diffusa Burm. f. dominated post-fire site 2018, Euphorbia hirta L. dominated post-fire site 2017, Hedyothis corymbosa (L.) Lam. dominated post-fire forest 2012 site, and Phyllanthus urinaria L. dominated post-fire 2015 and non-fire site. Only L. leucocephala (Lam.) de Wit and C. tetragona Benth. in the post-fire 2012 were found as woody species. This is not surprising since previously the MCNP management authority included these two species in their recovery program. The low IVI at post-fire 2012 might indicate the impact of introducing new species on previous soil seed banks, as planting seedlings would alter previous environmental conditions. It means that the impacts on different seedling emergence on soil seed banks after tillage or fertilization were different in this research. Heavy tillage and, to a lesser degree, light tillage were linked to a reduction in the percentage of viable seeds (Randriamalala et al. 2015). Santos et al. (2016) stated that areas with intensive agricultural practices or land rehabilitation were subjected to changes in species composition and population density and low similarity to species composition in the soil seed bank.

Herbaceous plants dominated in the soil seed bank across the five fire-condition sites with only a few woody species and shrubs appearing, such as $C$. diffusa Burm. f., P. urinaria L., Eleusine indica (L.) Gaertn. and Centotheca lappacea (L.) Desv. These four species were found at almost all of the post-fire sites, and they may have been the first to arrive. Small seeds, like herbaceous species, are one of the characteristics of pioneer species. Herbs and grasses are also very effective at mechanically stabilizing bank sediments through their root growth and stabilizing sediment and initiate bio-geomorphic succession and channel contraction (O'Donnell et al. 2016). Pioneer species produce a large number of seeds which leads to the high density of small seeds in soil seed banks. Small seeds, in addition to high seed development, appear to remain in soil seed banks for a long time and were previously associated with dormancy (Akinyemi et al. 2019). Similar to Sileshi and Abraha (2014), most of these woody species rarely recorded from soil seed bank flora belonged to shrubs and herbs but no climbers except in post-fire 2017 (Mikania micrantha Kunth).

Table 3. Two-way ANOVA comparing the total number of seedling emergence and species emergence across five fire conditions and three soil layers in MCNP and KBG.

\begin{tabular}{lcccc}
\hline \multirow{2}{*}{ Treatments } & \multicolumn{2}{c}{$\begin{array}{c}\text { Number of seedlings } \\
\text { emergence }\end{array}$} & \multicolumn{2}{c}{$\begin{array}{c}\text { Number of species } \\
\text { emergence }\end{array}$} \\
\cline { 2 - 5 } & N & Mean & N & Mean \\
\hline Soil layers & & $388.600 \mathrm{a}$ & 3 & $39.400^{\mathrm{a}}$ \\
Upper & 3 & $315.200 \mathrm{a}$ & 3 & $41.600^{\mathrm{a}}$ \\
Middle & 3 & $221.400 \mathrm{a}$ & 3 & $31.400^{\mathrm{b}}$ \\
Lower & 3 & 1.219 & & 7.490 \\
F (2,15) & & $0.344 \mathrm{~ns}$ & & $0.014^{*}$ \\
P & & & & \\
Post-fire Year & & & 5 & $40.000^{\mathrm{b}}$ \\
Non-Fire & 5 & $303.333^{\mathrm{a}}$ & 5 & $15.333^{\mathrm{a}}$ \\
Post-fire 2012 & 5 & $66.333^{\mathrm{a}}$ & 5 & $36.333^{\mathrm{b}}$ \\
Post-fire 2015 & 5 & $75.000^{\mathrm{a}}$ & 5 & $18.606^{\mathrm{a}}$ \\
Post-fire 2017 & 5 & $179.000^{\mathrm{a}}$ & 5 & $77.000^{\mathrm{c}}$ \\
Post-fire 2018 & 5 & $918.333^{\mathrm{b}}$ & 5 & 94.129 \\
F (4, 15) & & 13.070 & & $0.000^{*}$ \\
P & \multicolumn{5}{c}{$0.0013^{*}$} & & \\
\hline
\end{tabular}

Note: * Significant at level 5\%, ns: non-significant 
Table 4. Three dominant species of seedlings emergence across five fire-condition sites and three soil depths in Mount Ciremai National Park and Kuningan Botanic Gardens from November 2019 to February 2020

\begin{tabular}{|c|c|c|c|c|c|c|c|c|c|}
\hline \multirow{2}{*}{ Botanical name } & \multirow{2}{*}{ Family } & Non-Fire & \multicolumn{2}{|r|}{2012} & 2015 & \multicolumn{2}{|r|}{2017} & \multirow{2}{*}{\multicolumn{2}{|c|}{\begin{tabular}{|c|}
2018 \\
IVI (\%) \\
\end{tabular}}} \\
\hline & & $\sum$ IVI (\%) & $\sum$ & IVI (\%) & $\sum$ IVI (\%) & $\sum$ & IVI (\%) & & \\
\hline & \multicolumn{9}{|c|}{ Upper soil layer } \\
\hline Centotheca lappacea (L.) Desv. & Poaceae & & & & 2516.14 & & & 122 & 12.34 \\
\hline Commelina diffusa Burm.f. & Commelinaceae & & & & & & & 183 & 19.01 \\
\hline Eleusine indica (L.) Gaertn. & Poaceae & 3318.85 & & & & & & & \\
\hline Eupatorium odoratum $\mathrm{L}$. & Asteraceae & & & & 2618.14 & & & & \\
\hline Euphorbia hirta L. & Euphorbiaceae & & & & & & 26.36 & & \\
\hline Hedyotis corymbosa (L.) Lam. & Rubiaceae & & 13 & 19.44 & & & & & \\
\hline Laportea aestuans (L.) Chew & Urticaceae & & 12 & 18.33 & & & & & \\
\hline Leucaena leucocephala (Lam.) de Wit & Mimosaceae & & 15 & 21.67 & & & 31.67 & & \\
\hline Peperomia pellucida (L.) Kunth & Piperaceae & & & & & & 14.24 & & \\
\hline Phyllanthus urinaria $\mathrm{L}$. & Euphorbiaceae & 7847.69 & & & 3018.44 & & & 97 & 11.43 \\
\hline \multirow[t]{2}{*}{ Piper aduncum $\mathrm{L}$. } & Piperaceae & 1915.51 & & & & & & & \\
\hline & \multicolumn{9}{|c|}{ Middle soil layer } \\
\hline Commelina diffusa Burm.f. & Commelinaceae & & & & & 6 & 26.40 & 146 & 20.58 \\
\hline Cyperus cyperoides Kuntze & Cyperaceae & & 8 & 15.13 & & & & & \\
\hline Cyperus procerus Rottb. & Cyperaceae & & & & & 5 & 15.18 & & \\
\hline Digitaria longiflora (Retz.) Pers. & Poaceae & 7623.13 & & & & & & & \\
\hline Eupatorium odoratum L. & Euphorbiaceae & & & & 1813.28 & & & & \\
\hline Euphorbia hirta L. & Euphorbiaceae & & & & & 8 & 26.11 & & \\
\hline Hedyotis corymbosa (L.) Lam. & Rubiaceae & & 21 & 36.58 & & & & & \\
\hline Leucaena leucocephala (Lam.) de Wit & Mimosaceae & & 9 & 16.39 & & & & & \\
\hline Mitracarpus villosus (Sw.) Cham. \& Schltdl ex DC. & Rubiaceae & & & & & & & 82 & 11.60 \\
\hline Odontosoria chinensis (L.) J.Sm. & Dennstaedtiaceae & 6623.62 & & & & & & & \\
\hline Phyllanthus debilis J.G.Klein ex Willd. & Euphorbiaceae & & & & & & & 68 & 13.13 \\
\hline Phyllanthus urinaria $\mathrm{L}$. & Euphorbiaceae & & & & 4626.88 & & & & \\
\hline Piper aduncum L. & Piperaceae & 4720.18 & & & & & & & \\
\hline \multirow[t]{2}{*}{ Richardia brasiliensis Gomes } & Rubiaceae & & & & 1813.28 & & & & \\
\hline & \multicolumn{9}{|c|}{ Lower soil layer } \\
\hline Borreria alata (Aubl.) DC. & Rubiaceae & & & & & & & 37 & 8.47 \\
\hline Clibadium surinamense $\mathrm{L}$. & Asteraceae & & & & & 2 & 12.04 & & \\
\hline Commelina diffusa Burm.f. & Commelinaceae & & & & & & & 117 & 25.03 \\
\hline Cyperus compressus $\mathrm{L}$. & Cyperaceae & & 7 & 31.67 & & & & & \\
\hline Cyperus cyperoides Kuntze & Cyperaceae & & 6 & 28.33 & & & & & \\
\hline Euphorbia hirta L. & Euphorbiaceae & & & & 1212.80 & 11 & 31.61 & & \\
\hline Hedyotis corymbosa (L.) Lam. & Rubiaceae & & 7 & 31.67 & & & & & \\
\hline Odontosoria chinensis (L.) J.Sm. & Dennstaedtiaceae & 7629.14 & & & & & & & \\
\hline Oxalis barrelieri $\mathrm{L}$. & Oxalidaceae & & & & $\begin{array}{ll}6 & 12.08\end{array}$ & & & & \\
\hline Peperomia pellucida (L.) Kunth & Piperaceae & & & & & 22 & 63.21 & & \\
\hline Phyllanthus urinaria $\mathrm{L}$. & Euphorbiaceae & 5123.29 & & & & & & 83 & 20.60 \\
\hline Piper aduncum L. & Piperaceae & 4718.87 & & & & & & & \\
\hline Richardia brasiliensis Gomes & Rubiaceae & & & & 2324.72 & & & & \\
\hline
\end{tabular}

Note: IVI: Important Value Index

Table 5. Diversity index and richness index across five fire-condition sites and three soil depths in Mount Ciremai National Park and Kuningan Botanic Gardens

\begin{tabular}{|c|c|c|c|c|c|c|c|c|c|c|}
\hline \multirow{3}{*}{$\begin{array}{l}\text { Soil } \\
\text { layer }\end{array}$} & \multicolumn{10}{|c|}{ Post-fire site } \\
\hline & \multicolumn{2}{|c|}{ Non-fire } & \multicolumn{2}{|c|}{ Year 2012} & \multicolumn{2}{|c|}{ Year 2015} & \multicolumn{2}{|c|}{ Year 2017} & \multicolumn{2}{|c|}{ Year 2018} \\
\hline & H' & $\mathbf{R}$ & H' & $\mathbf{R}$ & H' & $\mathbf{R}$ & $\mathbf{H}^{\prime}$ & $\mathbf{R}$ & H' & $\mathbf{R}$ \\
\hline Upper & 2.39 & 7.20 & 2.55 & 4.00 & 3.01 & 6.87 & 2.49 & 4.91 & 3.49 & 11.98 \\
\hline Middle & 2.64 & 6.73 & 2.45 & 3.66 & 3.08 & 7.69 & 2.68 & 4.67 & 3.46 & 11.38 \\
\hline Lower & 2.68 & 6.87 & 1.97 & 2.64 & 2.96 & 5.91 & 1.68 & 2.87 & 3.26 & 10.21 \\
\hline
\end{tabular}

Note: H': Shannon-Wiener diversity index, d: species richness

The variations in floristic composition were likely caused by a particular assemblage of herbaceous plants. As a result, this community of species has the greatest potential for regeneration, with a diverse soil seed bank that has a longer lifespan (Santos et al. 2016). Furthermore, the lower number of woody species in soil seed banks may be attributed to most woody species limited residence period.

The highest diversity index was found in the post-fire 2018 site ranged from upper (3.49) to lower (3.26) soil layers (Table 5). High species diversities suggest a strong 
ecological balance and integrity, while low diversities indicate a small number of species that dominate the population (He et al. 2016). As a succession starting point, the high $\mathrm{H}^{\prime}$ index in the first year after a fire was overgrown by pioneer plants. On post-fire site 2018, an open and steep landscape, as opposed to other landscape sites, may be advantageous for wind-spread pioneer species seeds. Fire creates spaces in plant populations that can be filled by existing plants resprouting or new plants emerging from seed (Zida et al. 2020).

The lowest diversity index was found on the lower soil layer at a post-fire site 2017 with 1.68 followed by the lower soil layer at the post-fire site 2012 (1.97), suggesting that both were in the medium range. According to Santos et al. (2016), species richness of soil seed bank in young forest is highest in the first to fourth years and then decreased significantly. Contrary to Kwiatkowska-Falinska et al. (2014), the number of species in the seed bank and their diversity index (H') were lower in the following year after the fire than twelve years after the fire. It was thought that the seed bank's species composition reflects vegetation successional changes. Shannon-Wiener diversity index is not only related to organisms, but also to individual distribution uniformity, resulting in the phenomenon of Shannon-Wiener diversity index reduction when other species are introduced (He et al. 2016).

\section{Species richness}

The species richness index $(\mathrm{R})$ of all soil layers at the post-fire site 2018 was the largest in comparison to all study sites, while the species richness index (R) of all soil layers at post-fire site 2012 was the lowest (Table 5). The high $\mathrm{R}$ was likely resulted from the abundance of understory species in an open area of a post-fire site between 2015 and 2018, allowing pioneer seed to develop. Species richness index was higher in the first and fourth years in the young forest, then decreased dramatically over time (Santos et al. 2016). In this situation, the land rehabilitation program in the post-fire 2012 and 2017 sites had a distinct impact on the soil seed bank ecosystem. When compared to $\mathrm{R}$ in other post-fire areas, even though they were in the medium class, the seed bank in this location was still inadequate to help the restoration of post-fire ecosystem. In the future, exotic species should be introduced cautiously when vegetation restoration is carried out, in case they inhibit the growth of native species and reduce the biodiversity of the region (Hou et al. 2018). Putri et al. (2017) said that animals and human intervention could affect seed banks that store seeds from trees that once occupied the aboveground vegetation but no longer exist.

$\mathrm{R}$ had a high index on the non-fire site, indicating that undisturbed aboveground plant communities were significant supplementary sources for soil seed banks. $\mathrm{R}$ was widely used to investigate the multifunctional relationship between biodiversity and ecosystems. It was also a better indicator of ecosystem functions than species abundance as the simplest measure of biodiversity ( $\mathrm{Li}$ et al. 2021). According to Santos et al. (2016), human activities and temporal variation of precipitation caused changes in R. Liu et al. (2020) also indicated that H' and R of soil seed bank decreased with increasing invaded species of Acacia saligna (Labill.) H.L.Wendl.

\section{Correspondence analysis species of soil seed bank}

Each post-fire site had its own story about the timing of forest fires, the causes of forest fires, and land regeneration, all of which had a direct impact on the seedlings from the soil seed banks. Within 1-7 years, the community structure and non-fire site may have changed to the point that a new community type is emerging. Furthermore, habitat scale studies revealed some overlapping species moving between habitat types after a fire (Figure 3). The results of the upper soil layer revealed that the non-fire forest site was located far away from the other post-fire forest sites. There were no introduced species at that location, and the species on seedling emergence was substantially different from other sites. The dense plant communities influenced the emergence of seedlings from the soil seed bank of only aboveground plants. Aboveground plant communities served as essential supplementary sources for soil seed banks, similar to the function of seed rain, and the germination seedling density and species richness of soil seed bank (Daïnou et al. 2011; Liu et al. 2020).

Data analysis showed three distinct cluster groups were identified: the first cluster was found in areas with some introduced species (post-fire sites 2012 and 2017); the second cluster was found in areas with a higher probability of regular fire (post-fire sites 2015 and 2018), and the third cluster (no-fire site) was found in areas with no human or fire disturbances. Post-fire sites 2012 and 2017 were close together as were the post-fire sites 2015 and 2018. Clusters are useful for figuring out equations that govern an area's growth factors in comparison to other areas. Plants also revealed clear distributional regularities on soil factor gradients (He et al. 2016). Understory species, according to Yang et al. (2018) and Iacopetti et al. (2021), affected soil microbial biomass and evaluated resistance to drought but not its resilience. Due to their often high sensitivity to environmental conditions, understory plants form dynamic communities that respond in many ways to a broad range of habitat changes and disturbances over both short and longtimescale. The dynamic of seed banks play an important role in carrying germplasm, allowing the creation of new secondary forests and the re-acquirement of areas previously occupied by management authorities, among the processes involved in forest regeneration. However, given the difference in the time taken for the recovery of species composition and structure of forests, the dynamic of soil seed bank is complicated by the form and history of land use, as well as local climate changes (Santos et al. 2016). 

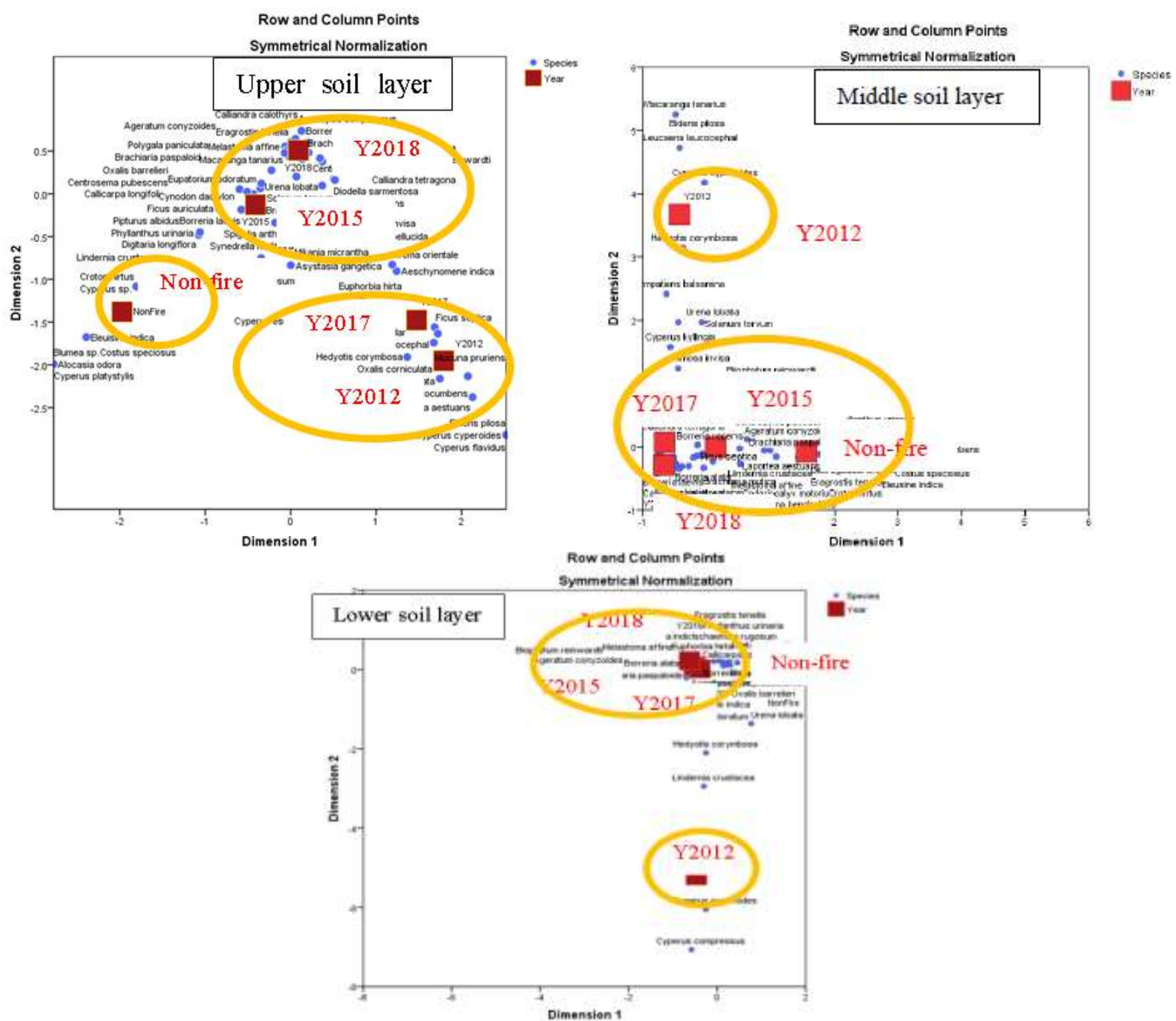

Figure 3. Correspondence analysis based on the composition of emergence seedlings across five fire-condition sites and three soil layers

For three soil layers in this analysis, the post-fire site 2012 showed a strong distance from other sites (Figure 3). On seedling emergence, there were some introduced species, but the species that dispersed into the post-fire region did not represent the native forest composition. The dominance of a few species in the seed rain and seed bank will affect vegetation recovery in early stages of succession and long-term forest dynamics (Blackham et al. 2013; Galloway et al. 2017). From post-fire sites 2018 to 2015, herbaceous and low-shrub growth types dominated the seed bank, meaning that these elements of ecosystem were able to survive forest fire and could actively return to the restored system without the need for reintroduction. These shrubs could play a key role in accelerating forest regeneration. The vegetation that emerged after a wildfire was the pioneer plant that played an important role in the natural forest recovery, including the forest that had been burned (Dwipa et al. 2020). Artificial perches can be set up in these post-fire areas to increase seed rain of animal dispersed organisms, according to this report. According to Ruwanza et al. (2013) and Zhang and Chu (2013), seed rains or seed sowing and seedling diversity of introducing tree plantations were too poor in native tree species to initiate forest succession. Reintroduction of some native species, such as Wendlandia densiflora (Blume) DC., Lithocarpus pallidus (Blume) Rehder, and Litsea noronhae Blume, has been proven an effective method in facilitating the plantation to become a more natural forest. Species $W$. densiflora (Blume) DC. were found in all post-fire sites while species L. palidus (Blume) Rehder dan L. noronhae Blume were found only in non-fire site. Therefore, another species option to planting some fast-growing species, such as Trema orientale (L.) Blume, which have fruits to attract birds in the early years of rehabilitation, and sowing some late-successional species to increase the diversity of soil seed bank and accelerate vegetation succession should be recommended on the abandoned post-fire site in MCNP and KBG. 
In conclusion, this study found that the dominant family compositions of soil seed banks on five sites were Poaceae, Asteraceae, Euphorbiaceae, Rubiaceae, Leguminosae and Piperaceae. The year of fire events and soil layers had varying species richness and number of seedlings. The upper soil layer of post-fire site 2018 had the highest species richness $(\mathrm{R}=11.98)$, while the lower soil layer of post-fire site 2012 had the lowest species richness $(\mathrm{R}=2.64)$. Variation of landscape also had strong effect on the species richness composition of young forest in environments, after disturbance. When carrying out restoration activities in post-fire areas, our findings suggest to use native species and species that are not competing with soil seed banks.

\section{ACKNOWLEDGEMENTS}

The authors thank Kuswandono, Head of Mount Ciremai National Park and Ali Jainal, Head of Kuningan Botanic Gardens, for research permission. First author thanks Saintek Scholarship and Ministry of Science and Technology and National Education, Republic of Indonesia for financial funding during this research.

\section{REFERENCES}

Akinyemi DS, Oseni SR, Oke SO. 2019. Effect of heat on soil seed bank of three contrasting physiognomies in Shasha forest reserve, Southwestern Nigeria. Acta Oecol 94 (20): 22-30. DOI: 10.1016/j.actao.2018.03.009.

Araújo FDC, Tng DYP, Apagua DMG, Coelho PA, Pereira, DGS, Santos M. 2017. Post-fire plant regeneration across a closed forest-savanna vegetation transition. For Ecol Manag 400: 77-84. DOI: 10.1016/j.foreco.2017.05.058.

Benoit DL, Kenkel NC. Cavers PB. 1989. Factors influencing the precision of soil seed bank estimates. Can J Bot 67 (10): 2833-2840. DOI: $10.1139 / \mathrm{b} 89-364$

Blackham GV, Thomas A, Webb EL, Corlett RT. 2013. Seed rain into a degraded tropical peatland in Central Kalimantan, Indonesia. Biol Conserv 167: 215-223. DOI: 10.1016/j.biocon.2013.08.015.

Bogor Botanic Gardens. 2016. Kebun Raya Kuningan. www.kebunrayadaerah.krbogor.lipi.go.id. [Indonesian]

Budiharta S, Meijaard E, Erskine PD, Rondinini C, Pacifici M, Wilson KA. 2014. Restoring degraded tropical forests for carbon and biodiversity. Enviro Res Lett 9 (11): 1-12. DOI: 10.1088/1748 9326/9/11/114020.

Chen W, Moriya K, Sakai T, Kayama L, Cao L. 2014. Post-fire forest regeneration under different restoration treatments in the Greater Hinggan Mountain area of China. Ecol Eng 70: 304-311. DOI: 10.1016/j.ecoleng.2014.06.016.

Daïnou K, Bauduin A, Bourland N, Gillet J, Feteke F, Doucet J. 2011 Soil seed bank characteristics in Cameroonian rainforests and implications for post-logging forest recovery. Ecol Eng 37 (10): 1499 1506. DOI: 10.1016/j.ecoleng.2011.05.004.

Davari N, Jouri MH, Ariapour A. 2011. Comparison of measurement indices of diversity, richness, dominance, and evenness in rangelands ecosystem (Case study: Jvaherdeh-Ramesar). J Range Sci 2 (1): 389 398.

Douh C, Dainov K, Joel J, Moutsambote J. 2018. Soil seed bank characteristics in two central African forest types and implications for forest restoration. $\mathrm{J}$ For Sci 409: 766-776. DOI: 10.1016/j.foreco.2017.12.012.

Dwipa I, Sumbari C, Anwar A. 2020. Plant soil seed bank analysis in wildfire former area of Mount Talang, West Sumatra, Indonesia. Biodiversitas 21 (1): 155-160. DOI: 10.13057/biodiv/d210120.

Ekasari I, Sadono R, Marsono D, Witono JR. 2020. Mapping multi stakeholder roles on fire management in conservation areas of Kuningan Regency. J Manajemen Hutan Tropika 26 (3): 254-267. DOI: $10.7226 / \mathrm{jtfm} .26 .3 .254$

Google Earth. 2019. Mount Ciremai National Park. www.googleearth.com Galloway AD, Holmes PM, Gaertner M, Esler KJ. 2017. The impact of pine plantations on fynbos above-ground vegetation and soil seed bank composition. S Afr J Bot 113: 300-307. DOI: 10.1016/j.sajb.2017.09.009.

Girard F, Payette S, Delwaide A. 2017. Patterns of early postfire succession of alpine, subalpine and lichen-woodland vegetation: 21 Years of monitoring from permanent plots. Forests 8: 1-14. DOI: 10.3390/f8090346.

Gunawan H. 2015. Secondary succession on disturbed forest area ex illegal cultivation in Mount Ciremai National Park, West Java. Pros Sem Nas Masy Biodiv Indon 1: 1591-1599. DOI: 10.13057/psnmbi/m010709. [Indonesian]

He M, Lv L, Li H, Meng W. 2016. Analysis on soil seed bank diversity characteristics and its relation with soil physical and chemical properties after substrate addition. PLoS ONE. 11 (1): 1-16. DOI: 10.1371/journal.pone.0147439.

Hou X, Liu S, Zhang Y, Wu X, Cheng F, Dong S. 2018. Interaction mechanism between floristic quality and environmental factors during ecological restoration in a mine area based on structural equation modeling. Ecol Eng 124: 23-30. DOI: 10.1016/j.ecoleng.2018.09.021.

Huebner CD, Regula AE, McGill DW. 2018. Germination, survival, and early growth of three invasive plants in response to five forest management regimes common to US northeastern deciduous forests. For Ecol Manag 425: 100-118. DOI: 10.1016/j.foreco.2018.05.037.

Iacopetti G, Bussotti F, Carrari E, Martini S, Selvi F. 2021. Understorey changes after an extreme drought event are modulated by overstorey tree species mixtures in thermophilous deciduous forests. For Ecol Manag 484 (4):118931. DOI: 10.1016/j.foreco.2021.118931.

Ismail AY, Kusmana C, Sudiana E, Widodo P. 2019. Short Communication: Population and stand structure of Cinnamomum sintoc in the Low Land Forest of Mount Ciremai National Park, West Java, Indonesia. Biodiversitas 20 (4): 1042-1047. DOI: 10.13057/biodiv/d200415.

Krebs CJ. 2014. Ecological Methodology. 3rd ed. Addison-Wesley Educational Publishers Inc, New York

Kwiatkowska-Falinska A, Jankowska-Blaszczuk M, Jaroszewicz B. 2014. Post-fire changes of soil seed banks in the early succesional stage of Pine forest. Pol J Ecol 62: 455-466. DOI: 10.3161/104.062.0307.

Li S, Liu W, Lang X, Huang X, Su J. 2021. Species richness, not abundance, drives ecosystem multifunctionality in a subtropical coniferous forest. J. Ecol Ind 120: 106911. DOI: 10.1016/j.ecolind.2020.106911.

Liu Z, Ge X, Fu Z, Liu J. 2020. Alternanthera philoxeroides invasion affects the soil seed bank of reed community. J. Env Exp Bot 180: 104196. DOI: 10.1016/j.envexpbot.2020.104196.

Luo X, Cao M, Zhang M, Song X, Li J, Nakamura A, Kitching R. 2017. Plant diversity soil seed banks along elevational gradients in tropical, subtropical and subalpine forests in Yunnan Province, Southwest China. J Plant Divers 39 (5): 273-286. DOI: 10.1016/j.pld.2017.10.001.

Magurran A. 2004. Measuring biological diversity, measuring biological diversity. Blackwell Publishing, United Kingdom.

Mwendwa BA, Kilawe CJ. Treydte AC. 2020. Effect of seasonality and light levels on seed germination of the invasive tree Maesopsis eminii in Amani Nature Forest Reserve, Tanzania. Glob Ecol Conserv 21: e00807. DOI: 10.1016/j.gecco.2019.e00807.

Numata I, Silva SS, Cochrane MA, D'Oliviera MV. 2017. Fire and edge effects in a fragmented tropical forest landscape in the southwestern Amazon. J For Ecol Manag 401: 135-146. DOI: 10.1016/j.foreco.2017.07.010.

O’Donnell J, Fryirs KA, Leishman MR. 2016. Seed banks as a source of vegetation regeneration to support the recovery of degraded rivers: A comparison of river reaches of varying conditions. Sci Tot Environ 542: 591-602. DOI: 10.1016/j.scitotenv.2015.10.118.

Odum E. 1996. Basics of Ecology. 3rd Ed. Gadjah Mada University Press, Yogyakarta. [Indonesian]

Piiroinen T, Valtonen A, Roininen H. 2017. The seed-to-seedling transition is limited by ground vegetation and vertebrate herbivores in a selectively logged rainforest. For Ecol Manag 384: 137-146. DOI: 10.1016/j.foreco.2016.10.037.

Putri W, Qayim I, Qadir A. 2017. Soil seed bank of two karst ecosystems in Bogor, Indonesia: Similarity with the aboveground vegetation and 
its restoration potential. J Trop Life Sci 7 (3): 224-236. DOI: 10.11594/jtls.07.03.07.

Randriamalala JR, Herve D, Letourmy P, Carriere SM. 2015. Effects of slash-and-burn practices on soil seed banks in secondary forest successions in Madagascar. J Agric Ecosyst Environ 199: 312-319. DOI: 10.1016/j.agee.2014.09.010.

Rodrigues RR, Gandolfi S, Nave AG, Aronson J, Barreto TE, Vidal CY, Brancalion PHS. 2011. Large-scale ecological restoration of highdiversity tropical forests in SE Brazil. For Ecol Manag 261 (10): 1605-1613. DOI: 10.1016/j.foreco.2010.07.005.

Ruwanza S, Gaertner M, Esler KJ, Richardson DM. 2013. The effectiveness of active and passive restoration on recovery of indigenous vegetation in riparian zones in the Western Cape, South Africa: A preliminary assessment. S Afr J Bot 88: 132-141. DOI 10.1016/j.sajb.2013.06.022

Santika T, Budiharta S, Law EA, Dennis RA, Dohong A, Struebig MJ, Medrilzam, Gunawan H, Meijaard E, Wilson KA. 2020. Interannual climate variation, land type and village livelihood effects on fires in Kalimantan, Indonesia. Glo Env Cha 64: 102129. DOI 10.1016/j.gloenvcha.2020.102129.

Santos DM, Santos JMFF, Silva KA, Araujo VK Araujo EL. 2016 Composition, species richness, and density of the germinable seed bank over 4 years in young and mature forests in Brazilian semiarid regions. J. Arid Environ 129: 93-101. DOI: 10.1016/j.jaridenv.2016.02.012.

Setyawati T, Narulita S, Bahri H, Raharjo GT. 2015. A Guide Book to Invasive Plant Species in Indonesia. Research, Developing and Innovation Agency, Ministry of Environment and Forestry Republic of Indonesia, Bogor. [Indonesian]

Shang Z, Yang Y, Wang Y, Shi J, Ding L. 2016. Soil seed bank and its relation with above-ground vegetation along the degraded gradients of alpine meadow. Ecol Eng 90: 268-277. DOI: 10.1016/j.ecoleng.2016.01.067.

Siahaan M, Purba E, Irmansyah T. 2014. Composition and weed seed bank density at variuos soil depth of crop planting area at Balai Benih Induk Tanjung Selamat. Agroekoteknologi 2 (3): 1189-1195. [Indonesian]

Sileshi D, Abraha B. 2014. Assessment of soil seed bank composition of woody species in Hgumbirda National Forest Priority Area, Northeastern Ethiopia. Momona Ethiop J Sci 6 (1): 25-44. DOI: 10.4314/mejs.v6i1.102413.

Soerjani M, Kostermans AJGH, Tjirosoepomo G. 1987 Weeds of Rice in Indonesia. Balai Pustaka, Jakarta. [Indonesian]

Sulistyawati E, Fitriana S. 2017. Post fire succession in Tegal Panjang Grassland, Mount Papandayan, West Java, Indonesia. Biodiversitas 18 (3): 1226-1233. DOI: $10.13057 /$ biodiv/d180347.

Tian X, Zhao F, Shu L, Wang M. 2013. Distribution characteristics and the influence factors of forest fires in China. For Ecol Manag 310: 460-467. DOI: 10.1016/j.foreco.2013.08.025.

Tucker MM, Kashian DM. 2018. Pre-fire forest remnants affect post-fire plant community structure and composition. For Ecol Manag 408: 103-111. DOI: 10.1016/j.foreco.2017.10.038.

Yang Y, Zhang X, Zhang C, Wang H, Fu X, Chen F, Wan S, Sun X, Wen X, Wang J. 2018. Understory vegetation plays the key role in sustaining soil microbial biomass and extracellular enzyme activities. Biogeosciences 15 (14): 4481-4494. DOI: 10.5194/bg-15-4481-2018.

Zhang H, Chu LM. 2013. Changes in soil seed bank composition during early succession of rehabilitated quarries. Ecol Eng 55: 43-50. DOI: 10.1016/j.ecoleng.2013.02.002.

Zida D, Sanou L, Diawara S, Savadogo P, Thiombiano A. 2020. Herbaceous seeds dominate the soil seed bank after long-term prescribed fire, grazing and selective tree cutting in savannawoodlands of West Africa. Acta Oecol 108: 103607. DOI: 10.1016/j.actao.2020.103607. 